\title{
Medieval Identities and 19th-Century National Imagination: Nailing Down Tribal Structure in the Medieval Eurasian Forest Zone and the Place of Finns, Karelians, Vepsians, and Lapps in It
}

(2010)

\author{
Jukka Korpela \\ University of Eastern Finland \\ jukka.korpela@uef.fi
}

\section{Traditional View and Soft Facts}

In his essay from the year 1816 "Ueber die Wohnsitze der Jemen, ein Beitrag zur Geschichte Neu-Finnlands," Aron Christian Lehrberg put the living areas of the Finnic peoples on a map (Lehrberg 1816: 103-236). Jooseppi Julius Mikkola, another St. Petersburg scholar, identified the tribes of the area of modern Finland which are recorded in Novgorodian medieval sources (Mikkola 1928: 181-189). Heikki Kirkinen has continued on the same path in his article "Finland in Russian Sources up to the Year 1323" (Kirkinen 1982: 255-275).

Russian and Finnish archaeologists have conducted field research in the area between Lakes Beloozero, Onega, Ladoga and the Arctic Sea during the last 150 years. They have identified cultural borders and produced maps which clarify the living areas of various tribes and peoples (Uino 1991: 12-32, Kirkinen, 1991: 35-38, Ocherki po istorii Karelii 1957: 41, articles in Problemy etnicheskoy istorii, 1994, Kochkurkina 1992: 124-129; Kochkurkina 2011: passim, Ryabinin 1992: 143-151, Ryabinin 2001: passim, Saksa, 1998: passim).

True, the peoples of Čud', Merja, Muroma, Ves', Mordva, zavolodč'kaja Čud', Perm', Pečora, Jam' (Jem'), Ugra, Kors', Čeremisi and Lib' are already recorded in the Kievan Primary Chronicle, and the first Novgorodian chronicle records the populations of Ižerjany, Sum', Vod' and Koreli (PVL: 8, 10, N1L, [ml] 6362, [ml] 6488, [ml] 6496, [ml] 6497, [st] 6577, [ml] 6579, [st] 6621, [st] 6651, [st] 6657, [st] 6699, [st] 6723, [st] 6737, [st] 6748, [st] 6749, [st] 6824, [st] 6826, [ml] 6892). Some of the people are mentioned also in western sources and sagas like Bjarmians, Finns and the odd expression of "Kirjalaland" (Korpela 2004: 22, 56-60; Aalto 2010: 115-138, 143-144). 
Perhaps the distributions of archaeological objects indicate ethnic and cultural areas, and they could be named with the tribal names of the chronicles. The final support for the tribal theory can be received from those philologists who have studied the language borders. The most modern fad has been the identification of the DNA inheritance of the modern populations. This seems to give the final, objective and scientific proof for the ethnographic maps of Fenno-Ugrians (Wiik 2002: 9395, 103, 116-117, 326-418, passim).

However, the theoretical framework of all these scholarly activities has been the idea of language-based tribal and national entities. The concept of language nations and their pre-historical migrations is a well-known $19^{\text {th }}$ century theory, which has been put aside today in all serious medieval studies of Europe, because supra-local identity formation and state-building is a most complicated and long lasting procedure (Korpela 2010c: 553-598).

\section{Identities and Sources}

The argumentation has some really weak points, and the connection of linguistic areas with the borders of material cultures is not so easy as it may look. First, there is more connecting of material evidence than separation of facts. The same criticism we can launch against most of the evidence of material differences presented by scholars. The metal objects were exceptions in daily life and therefore hardly formed any manifestations of identities (Korpela 2008b: 131-132, 220).

The area between Lake Beloozero and the Arctic Ocean can be divided in the medieval era into the area of permanent field cultivation in South, slash-and-burn agriculture in the middle area, and finally the area of semi-nomadic hunter-fishers in the North. The southern area was in close contact with the Viking trade network and under the economic, cultural and administrative influence of Novgorod from early on (Korpela 2008b: 140).

The ethnic names of the medieval sources form a most complicated issue. The problem is that the original authors have neither tried to specify some ethnic unities nor been able to do so. The authors have tried only to proclaim "otherness," that is the people who are other than us (Lind 1977: 286-323; Lind 2006: 246-257; Korpela 2008a: 42-43).

The idea of the modern philologists to construct linguistic areas is not any easier. Of course, scholars are able to identify historical variations in languages, but their identity-forming power cannot be known. Moreover, the philologists and DNA scientists are following the modern administrative borders. The result is the projection of the modern borders and reality into the distant past. 
Identity is a very complicated concept, too. The world of the Christian writers and the world of pagan backwoods fishermen were totally different. Lars Ivar Hansen has emphasized the relativism, changeability, and dynamics of processes involving ethnic classification and boundary establishment among social entities. In the context of early history, Hansen especially stresses the role of encounters with "the other", the definition of "us" in the socio-economic context of verbal and nonverbal discourses, that were involved in the processes of meeting with outsiders and in the asymmetrical relations of power that existed between population groups in the backwoods and the rulers of core regions (Hansen 1996: 32-39).

According to scholars of state formation, the self-identification of the inhabitants of borderlands is an elementary part of border formation and the integration of a realm. As state formation progressed further, this resulted in the formation of double identities among the provincial populations all over Europe. The people understood that they were members of a provincial society, but they also identified themselves as citizens of the royal realm (Gustafsson 2006: 8-9, 14-15; Ellis 2006: 26-42; Persson 2006: 110-118).

With regard to the Finnic tribes, we are speaking of identities and a supralocal reality among the medieval countrymen and semi-nomadic fishers of the backwoods. The view of an outsider could be different from that of an insider. For the Christian texts, there was a united group of pagans, while the pagans made distinctions between themselves and were enemies of each other and sometimes even more than against the Christians (cf. Eihmane 2009: 37-51).

\section{Life in the Medieval Backwoods}

We have to start from the other end and find out how Finnic forest dwellers were living during the Middle Ages, whom they encountered as others, and which kind of supra-regional human networks were formed, in the meaning of supra-local identity formation and consciousness.

According to the traditional literature, a population expansion of the area of Savo colonized the earlier almost unpopulated areas of East Fennoscandian forests during the early modern period. Paleoecological studies of lake sediments prove, however, the existence of a medieval cultivation in the entire area (Korpela 2008: 118-119).

In fact, heterogeneous Fenno-Ugric speakers populated forests from central Norway and Sweden over Finland, Lapland and Estonia to Central Siberia. In the northern areas they are and were Sámi speakers, but in the south they are today Finnic speakers, and east of Lake Onega other Fenno-Ugric speakers. The semi- 
nomadic living form of the people was based on multiform use of all natural resources. The forest dwellers were not visible in the eyes of the medieval powers, which did not acknowledge their rights. Therefore, the medieval documents deal with the areas as unpopulated and speak about their colonization when people became visible in the documents, because they were forced to change their way of life, to start cultivation, and to pay taxes (Korpela 2008b: 270-285; Korpela 2012a: 241-253).

The change of economy and integration into the European power system was slow. Areas of Southwest Finland and the southern shore of Lake Ladoga were agricultural areas with permanent fields in the Neolithic period. The southern Finnic areas were integrated into the Novgorodian and Swedish realms during the $12^{\text {th }}$ century (Korpela 2008b: 140).

Although the economy has influence on the culture, it does not define ethnicity. Indeed, the linguistic and cultural division of the Eastern Fennoscandian landscape differed from that prevailing in Scandinavia proper. While the border between the farmhouse settlements (fields) and forests coincided with that between the Fenno-Ugrian and Germanic language speakers in the latter region, the border between the two economic systems in the former one ran through the Finnic populations. It should be noted in this connection that Finnic folklore makes a clear distinction between village society and the forest (Hansen-Olsen 2004: 62-64; Zachrisson 1997a: 171-172; Zachrisson 1997: 189-192, 219; Mulk 1996: 49-50; Taavitsainen, Vilkuna and Forssell 2007: 89-90; Tarkka 1998: 130-132; Lamberg, 2006: 121-132).

When the European princely power was established, it also had to define its relation to the forest dwellers. Royal Steward Knut Jonsson called the people homines siluestres et vagi, vulgariter dicti Lappa, in September, 1328. Sometime later, an unknown German chronicler counted the Lapps and Finns among wilde lude (the savage peoples) (FMU I 360, Ex prima continuatione Detmari a. 1395 - 1400, a. 1399: 205; cf. also Lamberg 2006: 121-125).

When King Magnus Ericsson confirmed the rights of Christian colonists in the lands of the north ("Lappmarken") in 1340, he ordered that the colonists should have free ownership over all that they had taken into use and that they came under the Swedish Law. When his son, King Eric Magnusson, renewed the privileges, 1358, he explained that the colonists "are there for the increase of the Swedish Kingdom and Christianity" (Diplomatarium Suecanum IV 3473; FMU I 675).

When the bailiff of Häme, Magnus Kazi, donated the house of Kantala for the Requiem Mass of the late Bo Jonsson in 1390, he placed restrictions on his donation, one of which concerned "the Lapps that belonged to the house". Similarly, the bailiff of Norrbotten, Sten Henriksson, decided in 1454 that a group of Lapps who had arrived from Häme were not the king's Lapps but belonged to the Birkkarlar (private 
tax collectors) of Piteå and Luleå. Forest people seem to have been objects which could be owned (Registrum ecclesiae Aboensis 1890: 187, 269; FMU IV: 2959; Suvanto 1985: 197).

The Supervision Book of 1597 of "Muscovite Lapp pogosts" states expressively: "And in Kuittijärvi there were 33 Lapps living in the forest. And they paid 11 bows in tax to the ruler. In the year $99(7099=1590 / 1591)$ they were killed by foreigners. Now five new Lapps have arrived in Kuittijärvi and they pay one and a half bows." These people just came into existence from "nowhere" when they were included on the tax rolls of the prince (Dozornaja kniga lopskikh pogostov 1597 [1987]: 215 [1. $67-67 \mathrm{ob}]$.$) . In the same way we know that the surroundings of$ Kuittijärvi (Vuonninen) had belonged to agricultural regions already in the $6^{\text {th }}$ century $\mathrm{AD}$ and therefore none of the Lapps arrived in some unpopulated area (Alenius et al. 2011: 142-163). The Lapps form, however, a special and from our point of view interesting issue in the Russian written sources. They are not mentioned in the proper medieval sources. Old chronicles do not speak about Lapps. The first reference is in the Hagiograph of Lazarij of Murom, which dates to the $13^{\text {th }}$ century, but the text is much younger. Although the Novgorodians were most active in Lapland according to modern scholars, the Lapps did not live in the world of the medieval Novgorodians (Korpela 2008a: 48).

There is a similar finding about non-existing people from Swedish East Finland. Judge Jesper Sigfridsson decided in Tavisalmi in 1564 that a peasant named Per Ollikainen could keep a field that the "fisher peasants" had cleared. Who were these fisher peasants (fiiskare bönder) and why did Per Ollikainen receive their fields? According to the "law" of the slash-and-burn culture, the field belonged always to the person who had cleared it, and now the king's judge was making a distinct exception in this respect. Is it possible that they were hunter-fishers who did not pay taxes and were therefore judged to be living outside the realm and beyond the king's protection? (Domböcker för Savolax 1954: 177)

Thus the big and original encounter prevailed between the forests and fields and was dealt as the division between the Lapps and Christians.

It is much more difficult to say anything concerning the encounters inside the forests. The populations were heterogeneous and living according to local possibilities. There is no evidence concerning some supra-local social or cultural structures. Every co-resident group seems to have had a seita (a deity) of its own in the neighbourhood of its dwelling place, and therefore the cults have not formed structures to create a sense of togetherness over larger areas. Nor did the maintenance of roads require any co-operative efforts, because waterways formed the only communication systems. The nomadic system left people free to move and encounter other areas and other people, too. But in East Fennoscandia the area of migration was much more limited than, e.g., in Siberia. The yearly circulation 
happened within an area of only some tens of kilometres (Mäki 2004: 144; Halinen 2005: 87, 92-93; Korpela 2011b: 97-101).

The only larger get-togethers are described in Kalevala in connection with brewing beer. But also here the people are from rather near and perhaps relatives. Because the nature of family formation is unclear, it is possible that the co-resident groups had been seasonally larger and smaller. Much manpower was needed on certain occasions like salmon fishing or moose hunting, but not in other times (Korpela 2004: 282; Korpela 2008b: 55, 65; Korpela 2011b: 98; Korpela 2011a: 124-136). But also here the people arrived from the neighbourhood and were relatives. The general genetic inheritance of the population reveals closed societies, and the male inheritance patterns reveal small population groups which had not many male contacts outside of the backwoods but had grown steadily within the same area after the Glacial Period. This notion ruins all visions concerning some extensive pre-historical migrations from outside areas into the local living areas of the Finnic speakers (Korpela 2008b: 119-128).

War and enemies always create togetherness and supra-local identity, but these phenomena were rare in the Finnic backwoods until the state formation of the early modern period (Korpela 2010b: 108-112; Korpela 2007: 76-77). Therefore, the local identity was formed around the co-resident group, without any supra-local extensions, and the encounters took place against other similar Finnic-speaking groups. This leads to the conclusion that there could not exist some supra-local tribal structure and linguistic identity among the populations.

\section{A Sovereign King}

The formation of sovereign territorial Royal power was a pan-European political phenomenon after the $14^{\text {th }}$ century. The process reached Northeast Europe in the last years of the $15^{\text {th }}$ century and was realized in administration building, new parish formation, and registration of taxpayers. Realm formation created a new division between Finnic speakers, too, because the rulers tried to keep their subjects within the state regulations and indoctrinate a loyalty towards the ruler among them. The definition of a state border through Finnic backwoods was a new issue between Stockholm and Moscow. The old Nöteborg peace treaty of 1323 concerned only Baltic trade and divided areas of influence on the Karelian Isthmus. The new interest was born in the 1460s. At this time the Swedish sources started to handle Russians as physical enemies in Finland (Korpela 2010b: 108-112; Korpela 1997: 161-172; Korpela 2006a: 373-384; Korpela 2002: 384-397; Korpela 2006b: 454-469). 
King Gustavus wrote on the 18th December, 1555, that the peasants were defending their "own border" in the Nyslott bailiwick in Eastern Finland (Konung Gustaf den förstes registratur, no. 25: 509). The king believed that his policy of identity building has formed a supra-local togetherness feeling and loyalty towards his realm.

The policy of power formation and identity building had a linguistic aspect, too. The father of the written Finnish language, the Bishop of Åbo Michael Agricola, created it especially as an instrument for the implementation of the Swedish administration. He formed for this purpose many new words which were not familiar for the forest dwellers. He borrowed the words mainly from Swedish--e.g., for tuomari (Finnish) 'judge' from domare (Swedish). The new Finnish church expansion integrated also the populations of the backwoods into the new power and introduced Christianity into pagan backwoods, although this Christianity remained very superficial. Perhaps one explanation for the disappearance of the Sámi population from the southern forests was their integration into the expanding Finnish society, which opened possibilities for a social rise. The Sámi speakers disappeared from sources of the southern regions before the late $17^{\text {th }}$ century, but instead of emigrating perhaps they only changed the economic system, which caused also a language shift of the population (Korpela 2012a: 252-253).

Similarly, the Karelians of the Muscovite realm took now their administrative and Christian vocabulary from Russia, which made a fundamental difference between the Karelian language and the Finnish language. For example, the word for judge in Karelian is sutja and in Russian sud'ja. This kind of difference between the Finnish and Karelian languages did not exist in the medieval forests. Unfortunately, we have no evidence from the early efforts to form a proper Karelian written language. According to sources, Feodorit Kol'skij had similar ideas in the 1540s as Michael Agricola did at about the same time, but if this is true, he did not have the same success. Christianization proceeded in the Russian area the same way as in Swedish Eastern Finland. Although the people were not deeply Christianized before the $19^{\text {th }}$ century, they were handled as Christians, and a fictitious Christian division between Lutheran Finns and Orthodox Karelians was recorded in official documents (Korpela 2008b: 108-110, 145; Korpela 2010a: 218).

The separation of languages and formation of linguistic and cultural borders were purely political processes in the backwoods and connected with the formation of sovereign states. The meaning of the early modern state building was the formation of a border between Sweden and Moscow and a division of Finnic forest dwellers between agricultural Finns/Karelians and fishermen Sámi. 


\section{Proto-nations and Original Borders}

The late medieval notion of territorial sovereignty presupposed that the King had the supreme power over a certain territory, which was marked with exact borders, and all human beings on this territory were his subjects. The building of a state identity was therefore one of the core issues in the legitimatization of power. A legitimate existence of a people presupposed that the state's people as well as its territorial borders belonged to the original creation of God. Generally, the medieval argumentation stressed the role of authority and its connection to God's original salvation plan (Gurjewitsch 1982: 11, 65, 68, 160-62, 211-213, 327, 339, 370).

This way of thinking put historians to the task of constructing genealogical presentations concerning the national past of the nation-state. These presentations tried to show the present nations as direct descendants of the sons of Noah Shem, Ham, and Japheth. When God dislocated peoples and mixed languages after the erection of the Tower of Babel, he sent various family groups in different directions. Europe was the territory of the family of Japheth. When God had designated suitable living areas for all, he showed also natural borders (lakes, rivers, mountains, valleys) between the territories of the nations. The result was therefore not only learning about the birth of proto-nations but also of their eternal borders, as defined by God. Among these histories was Cronica regni Gothorum (written about 1471) by Ericus Olai, who explained the history of the Swedish nation (Nygren 1980: 603-604).

This book was essential for the Finnish eastern border and Finnish identity, too. The late $15^{\text {th }}$ and $16^{\text {th }}$ century Swedish political literature described Sweden as the historical bridgehead against the expansion of Muscovy and the Orthodox church. The message emphasized especially the role of the Finnish eastern border as a line which divided the two cultural spheres from each other and stressed the hostile feelings and encounters along the borderline, which was an eternal eastern border according to this view. Finnish self-identity soon took elements from this message for itself and later it formed the whole Finnish understanding concerning the historical role of Finns, at the same time as the Swedes themselves started to give up the whole idea of their historical role in the East (Korpela 2006c: 281-283).

At the same time the Muscovite realm built its identity around the holy role of the Czar as the protector of Orthodox Christians against eastern pagans and western heretics. This message was introduced into the Finnic forests of the North when the Muscovite church started an active Christianization and parish formation hand in hand with administration building in the $16^{\text {th }}$ century (Korpela 2001: 171210; Korpela 2008b: 256-258, 265-267).

The development has an enormous meaning for border-building and the separation between the Finns and Karelians. On both sides, royal powers declared 
the overriding, historical role of their state subjects as the protectors of the power centers' Christian values, while the main enemy of these values was people beyond the local border. The border was only now created in the landscape, and at the same declared as the border of the originating state and animosity towards others. The separation was supported by the administrative development and integration with the power centres of Stockholm and Moscow, by the cutting of long cultural and economic ties, and at the same the development of local languages in the direction of each power centre (Korpela 2006c: 283-286; Korpela 2008b: 123, 324-325).

\section{Nationalism in the Backwoods}

The last step was taken in the period of National Romanticism after the late $18^{\text {th }}$ century, and especially after the formation of the independent republics of Finland and Estonia and during the early Soviet Leninistic national policy after the October Revolution of 1917.

Eighteenth-century scholarship resulted in the rise of national scholarship in various areas of the humanities. Language standards were developed and national literature created. Simultaneously the interest was directed to the past of the local language speakers. History is always an interpretation, and the $19^{\text {th }}$ century historians interpreted the past from the perspective of local language speakers. They created a totally new history: the history of the nation and the histories of the nations.

Historians identified the roots of the present nations by referring to certain facts of medieval history. In the same spirit they adapted the early modern protohistories as sources for the historical role of the new nations. Now the focus was on the story about the development of nations, their historical living areas, missions and roles. The nations of Finns, Lapps, Karelians, Vepsians, Votians etc. were born in medieval history, and soon their living areas formed the historical Finland, Karelia, Estonia, etc.

Extensive elementary school teaching was organized after the middle of the $19^{\text {th }}$ century in Northeast Europe. The historical explanation of the national past was the focus of the teaching. The national epos of Kalevala was most important for the self-respect of the Finnish speakers, when they started to create their own role among the European cultural nations. This message had to be told also to the pupils of the elementary schools, because it created a common dogma for the support of patriotism.

Learning about independent nations and their original past was the paradigm of history in the early $20^{\text {th }}$ century. Therefore, it is natural that the original cultural areas were separated from each other also in the north. This early modern 
development separated the Finns from Karelians and left the pagan forest dwellers among the "Lapp" population. The Christian mission and local administration formation expanded to Lapland proper during the $18^{\text {th }}$ century. Those populations which had a permanent living place soon were integrated into the accounts of these new developments. However, reindeer pastoralism had grown substantially during the early modern period. Now the pastoralists were separated from fishermen and field cultivation peasants and marginalized to the most northern areas. The reindeer herders were classified in the $19^{\text {th }}$ century administrative registers as Sámi. Later a Sámi national identity was developed only among these people (Läheenmäki 2004: 290-298, 474-475).

Because this development was so late, the Sámi could not occupy their own territory. However, they were able to join to the political movement of the so-called aboriginal peoples or first nations and to complain about the conquest of their traditional territories by Swedes, Finns and Russians. Similar kind of claims has been made lately by other North Siberian Fenno-Ugrians, too. This claim is partly true, but mainly the question is about the procedure of European state formation, which created the concept of landownership, first in Central Europe in early medieval times and after the $15^{\text {th }}$ century in North Europe, too. The Fenno-Ugric forest dwellers did not have any understanding of land ownership, because they did not need one. Instead they had their own well-developed system of usage rights (Korpela 2012b: 222-240).

In the south the division between Karelians and other Finnic populations began during the early modern period. The Estonians were, like Finns proper, Lutheran Christians after the $16^{\text {th }}$ century and belonged to the West European culture already during the Middle Ages. Thus they were clear cases, but the original Ingrians, Vepsians, and Vatja [Votes] were not so easy to separate from each other and from Karelians. When the Orthodox Ingrians ran away from the shores of River Neva to Central Russia after the Swedish conquest in the early $17^{\text {th }}$ century, the area was resettled by Lutheran Finns. Their difference here is clear.

Most educational for the fictive dogmatic nation creation is the lot of the Vepsians. The Karelian area is linguistically rather heterogeneous. The difference between Vepsians and Karelians may have been based on the fact that Vepsians formed early permanent agricultural village societies and therefore Novgorodian Chronicles used a special name of Ves' for them.

The nineteenth-century historians took this name, and identified the local culture as a national Vepsian culture different from all others. The young Soviet Union strongly supported in the 1920s the Leninistic national programme. This policy created the Karelian republic as a national state for Karelians. In the same context, the Ves' nationality was also developed, a grammar for the language of Ves' was created, which finally resulted in the birth of the historical people of Ves' and 
the emergence of its own identity. The presentation of Svetlana Kochkurkina about the ethnogenesis of Vepsians is brilliant, but she does not remark on how scholars have projected only something from our own modern world into medieval history (Kochkurkina 2006: 178ff; Korpela 2010c: 553-598).

Despite of the early modern idea of eternal borders, the factual borders are most modern and heterogeneous phenomena. Although the border between Finland and Russia created the division between Finns and Karelians in the $16^{\text {th }}$ century, it has not followed this division after that but changed a lot. Religious, cultural and language borders go their own ways and do not form any clear line of the separation. The modern border is the border of Schengen, and therefore is a strong political, economic, and juridical barrier but between Russian citizens and the citizens of Finland, not between Finnic tribes.

\section{References}

Aalto, Sirpa. (2010) Categorizing Otherness in the King's Sagas. Joensuu: Publications of the University of Eastern Finland. Dissertations in Social Sciences and Business Studies, No. 10.

Alenius, Teija; Matti Saarnisto; Jussi-Pekka Taavitsainen; and Juha-Pekka Lunkka. (2011) Records of land use and medieval settlement history in Vuonninen, Dvina Karelia, Northwest Russia. Geoarcheology 26:1, January-February, pp. 142-163.

Diplomatarium Suecanum eller Svenskt Diplomatarium utgivet av Riksarkivet, 1 10, Holmiae, 1829-2000.

Domböcker för Savolax 1559 och 156 -1565 utgivna av riksarkivet redigerade av Kauko Pirinen, Finlands äldsta domböcker I, Helsingfors, 1954.

Dozornaja kniga lopskih pogostov 1597g. Istorija Karelii XVI - XVII vv. v dokumentah, I, Petrozavodsk - Joensuu, 1987.

Eihmane, Eva. (2009) The Baltic Crusades: A Clash of Two Identities. In Alan V. Murray (ed.), The Clash of Cultures on the Medieval Baltic Frontier (pp. 3751). Farnham: Ashgate.

Ellis, Steven. G. (2006). Integration, Identities and Frontiers in the British Isles: A European Perspective. In Harald Gustafsson and Hanne Sanders (eds.), Vid gränsen. Integration och identiteter i det förnationella Norden (pp. 19-45). Lund: Centrum för Danmarksstudier vid Lunds universitet 10. 
FMU = Finlands medeltidsurkunder samlade och i tryck utgifna af Finlands statsarkiv genom Reinh. Hausen, I-VIII, Kejserliga senatens/ Statsrådets tryckeri: Helsingfors 1910-1935.

Gurjewitsch, Aron. (1982) Das Weltbild des mittelalterlichen Menschen. München: Beck.

Gustafsson, Harald. (2006) Att testa gränser. En inledande problematisering. In Harald Gustafsson and Hanne Sanders (eds.), Vid gränsen. Integration och identiteter $i$ det förnationella Norden (pp. 7-18). Lund: Centrum för Danmarksstudier vid Lunds universitet 10.

Halinen, Petri. (2005) Prehistoric Hunters of Northernmost Lapland. Settlement patterns and subsistence strategies. Helsinki: Iskos 14.

Hansen, Lars Ivar. (1996) Interaction between Northern European sub-arctic societies during the Middle Ages: Indigenous peoples, peasants and state builders. In Magnus Rindal (ed.), Two Studies on the Middle Ages. Oslo: The Research Council of Norway: KULTs skriftserie No. 66.

Hansen, Lars Ivar, and Bjørnar Olsen. (2004) Samenes historie fram til 1750. Oslo: Cappelan Akademisk Forlag.

Kirkinen, Heikki. (1982) Finland in Russian Sources up to the Year 1323. Scandinavian Journal of History 7, pp. 255-275.

Kirkinen, Heikki. (1991) Inkerin keskiaika ja uuden ajan alku vuoteen 1617. In P. Nevalainen - H. Sihvo (eds.), Inkeri - Historia, Kansa, Kulttuuri (pp. 35-66). Helsinki: SKS toimituksia 547.

Kochkurkina, Svetlana. (1992) Etnokul'turnye kontakty drevnikh karel i vepsov v epokhu srednevekov'ya. In A. N. Kirpichnikov - E. A. Rjabinin (eds.), Drevnosti slavyan i finno-ugrov (pp. 124-129). Sankt-Peterburg: RAN.

Kochkurkina, Svetlana. (2006) Ves'. In Sovremennaya nauka o vepsakh: dostizheniya i perspektivy (pamyati N. I. Bogdanova). Petrozavodsk.

Kochkurkina, Svetlana. (2011) Istoriya i kul'tura narodov Karelii i ikh sosedey (srednie veka). Petrozavodsk: Karel'skiy nauchnyi centr.

Konung Gustaf des förstes registratur med understöd af statsmedel i tryck utgifvet af kongl. Riks-Archivet genom Victor Granlund, 1 - 29, Handligar rörande Sveriges historia, första serie. Stockholm: Norstedt \& Söner, 1861-1916.

Korpela, Jukka. (1997) "The Russian threat against Finland" in the western sources before the peace of Noteborg (1323). Scandinavian Journal of History 22, pp. $161-172$.

Korpela, Jukka. (2001) Prince, Saint and Apostle - Prince Vladimir Svjatoslavič of Kiev, his Posthumous Life, and the Religious Legitimization of the Russian Great Power. Veröffentlichungen des Osteuropa-Institutes München, Reihe: Geschichte, 67 Stuttgart: Harrassowitz. 
Korpela, Jukka. (2002) Finland's Eastern Border after the Treaty of Nöteborg: An Ecclesiastical, Political or Cultural Border. Journal of Baltic Studies 33:4, pp. 384-397.

Korpela, Jukka. (2004) Viipurin linnaläänin synty. Viipurin läänin historia II. Helsinki: Karjalan kirjapaino.

Korpela, Jukka. (2006a) Beyond the borders in the European North-East. In O. Merisalo (ed.), Frontiers in the Middle Ages (pp. 373-384). Louvain-laNeuve: Textes et études du moyen âge 35.

Korpela, Jukka. (2006b) Keskiaikaikainen itäraja läpi itäisen Fennoskandian metsävyöhykkeen - mikä se on! Historiallinen Aikakauskirja, pp. 454-469.

Korpela, Jukka. (2006c) Die Schwedische Ostgrenze von Nöteborg bis Kardis: Eine Kirchengrenze, politische Grenze oder Kulturgrenze 1323-1660? Eine Region des Ost-West-Gegensatzes? In J. Hackmann und R. Schweitzer (eds.), Nordosteuropa als Geschichtsrgion (pp. 267-286). Lübeck: Veröffentlichungen der Aue-Stiftung, 17.

Korpela, Jukka. (2007) Ruotsi, Novgorod ja Moskova. In Pertti Haapala (ed.), Suomen historian kartasto (pp. 76-77). Karttakeskus: Jyväskylä.

Korpela, Jukka. (2008a) North-Western "Others" in Medieval Rus'ian Chronicles. Uchennye zapiski petrozavodskogo gosudarstvennogo universiteta, n:o 2 (93), Avgust, 2008 (Obshchestvennye i gumanitarnye nauki).

Korpela, Jukka. (2008b) The World of Ladoga. Society, Trade, Transformation and State Building in the Eastern Fennoscandian Boreal Forest Zone c. 10001555. Berlin: Hopf Nordische Geschichte 7.

Korpela, Jukka. (2010a) Feodorit (Theodorit) Kol'skii - Missionary and Princely Agent. In Ludwig Steindorff (ed.), Religion und Integration im Moskauer Russland (pp. 201-226). Berlin: Forschungen zur osteuropäischen Geschichte 76.

Korpela, Jukka. (2010b) Keskiajan idänuhka. In Hannele Klemettilä (ed.), Suomalainen sotilas I. Muinaisurhosta nihtiin (pp. 108-112). Hämeenlinna: Weilin \& Göös.

Korpela, Jukka. (2010c) „Nationen“ und „Stämme“ in der Mittelaltergeschichte des östlichen Europas - Ein Teil des nationalen Selbstbewusstseins des 19. Jahrhunderts. In Karl Kaser et al. (eds.), Kontinuitäten und Brüche: Lebensformen - Alteingesessene - Zuwanderer von 500 bis 1500 (pp. 553598). Klagenfurt: Wieser Enzyklopädie des europäischen Ostens 12.

Korpela, Jukka. (2011a) Aspekter till östfinska familjen under medeltiden - indicier till ett annorlunda system. In Lars Ivar Hansen et al. (eds.), Nordens plass $i$ middelalderens nye Europa: Samfunnsomdanning, sentralmakt og periferier. Speculum Boreale 16 (pp. 124-136). Tromsø: Orkana Akademiska. 
Korpela, Jukka. (2011b) In Deep, Distant Forests. In Marko Lamberg et al. (eds.), Physical and Cultural Space in Pre-industrial Europe: Methodological Approaches to Spatiality. Lund: Nordic Academic Press.

Korpela, Jukka. (2012a) Migratory Lapps And the Population Explosion Of Eastern Finns: The Early Modern Colonization Of Eastern Finland Reconsidered. In Charlotte Damm and Janne Saarikivi (eds.), Networks, Interaction, Emerging Identies in Fennoscandia and Beyond, Mémoires de la Société FinnoOugrienne 265(pp. 241-261). Helsinki: Société Finno-Ougrienne.

Korpela, Jukka. (2012b) "Och starec Sergej köpte land och vattenområden och skogar och fiskeplatser". In Sverre Bagge et al. (eds.), Jordegendom, skenköp och det europeiska väldet $i$ östra Fennoskandien under senmedeltiden. Statsutvikling i Skandinavia i middelalderen (pp. 222-240). Oslo: Dreyers forlag.

Lamberg, Marko. (2006) Finns as aliens and compatriots in the late Medieval Kingdom of Sweden. In O. Merisalo (ed.), Frontiers in the Middle Ages (pp. 121-132). Louvain-la-Neuve: Textes et études du moyen âge, 35.

Lehrberg, A. C. (1816) Untersuchungen zu Erläuterungen der älteren Geschichte Russlands. St. Petersburg: Kaiserliche Akademie der Wissenschaften.

Lind, John. (2006) Problems of Ethnicity in the Interpretation of Written Sources on Early Rus'. In Juhani Nuorluoto (ed.), The Slavicization of the Russian North (pp. 246-258). Helsinki: Slavica Helsingiensia 27.

Lähteenmäki, Maria. (2004) Kalotin kansaa. Rajankäynnit ja vuorovaikutus Pohjoiskalotilla 1808-1889. Helsinki: SKS: Historiallisia tutkimuksia 220.

Mäki, Jari. (2004) The Annual Cycle of the Settlements of the Circumpolar Peoples. Helsinki: Early in the North Volume 5, Iskos 13.

Mikkola, J. J. (1928) Venäläisistä kronikoista pohjoismaiden keskiajan historian lähteinä. Historiallinen Aikakauskirja, pp. 181-189.

Mulk, Inga Maria. (1996) The Role of the Sámi in Fur Trading during the Late Iron Age and Nordic Medieval Period in the Light of the Sámi Sacrificial Sites in Lapland, Northern Sweden. Acta Borealia 13, $47-80$.

$\mathrm{N} 1 \mathrm{~L}=$ Novgorodskaya pervaya letopis ' starshego $(=\mathrm{st})$ i mladshego $(=\mathrm{ml})$ izvodov. Polnoe sobranie russkikh letopisej III, Moskva, 2000.

Nygren, Ernst. (1980) Cronica regni Gothorum. Kulturhistoriskt lexikon för nordisk medeltid från vikingatid till reformationstid II (Blik - Data) (pp. 603-604). Viborg: Rosenkilde og Bagger.

Ocherki po istorii Karelii (1957). V. N. Bernadskiy et al. (eds.). Petrozavodsk: Karel'skiy filial AN. 
Persson, Stefan. (2006) Riksgräns eller "riskgräns"? Gränsinventering i Göinge vid mitten av 1500-talet. In Harald Gustafsson and Hanne Sanders (eds.), Vid gränsen. Integration och identiteter i det förnationella Norden (pp. 107-121). Lund: Centrum för Danmarksstudier vid Lunds universitet 10.

$\mathrm{PVL}=$ Povest' vremennykh let . Podgotovka teksta, perevod, staty i kommentariy D. S. Lihacheva pod redakciey V. P. Adrianovoi-Peretec. Izdannie vtoroe ispravlennoe i dopolnennoe. Sankt-Peterburg, 1996.

Registrum ecclesiae Aboensis eller Åbo domskyrkas svartbok med tillägg ur Skoklosters codex Aboensis. I tryck utgifven Finlands statsarkiv genom Reinh. Hausen. Helsingfors 1890.

Ryabinin, E. A. (1992) Chud' vodskoi pyatiny. In A. N. Kirpichnikov - E. A. Ryabinin (eds.) Drevnosti slavyan i finno-ugrov (pp. 143-151).. SanktPeterburg: RAN

Ryabinin, E. A. et al. (eds.). (1994). Problemy etnicheskoi istorii i mezhetnicheskikh kontaktov pribaltiisko-finskikh narodov, Pamyati D. V. Bubrikha. Sbornik nauchnykh trudov. Sankt-Peterburg.

Ryabinin, E. A. (2001) Vodskaya zemlya velikogo Novgoroda (resultaty arkheologicheskikh issledovaniy 1971 - 1991gg.), Sankt-Peterburg: RAN.

Saksa, Aleksandr. (1998) Rautakautinen Karjala. Muinais-Karjalan asutuksen synty ja varhaiskehitys. Joensuu: Studia Carelica Humanistica 11.

Suvanto, Seppo. (1985), Keskiaika. Suomen historia II, Espoo: Weilin \& Göös.

Taavitsainen, Jussi-Pekka, Janne Vilkuna, and Henry Forssell. (2007) Suojoki at Keuruu - a mid $14^{\text {th }}$ century site of the wilderness culture in the light of settlement historical processes in Central Finland. Helsinki: Annales Acamediae Scientiarum Fennicae, humaniora 346.

Tarkka, Lotte. (1998) Sense of the Forest. Nature and Gender in Karelian Oral Poetry. In Satu Apo et al. (eds.), Gender and Folklore. Perspectives on Finnish and Karelian culture (pp. 92-142). Helsinki: SKS: Studia Fennica Folkloristica 4, 1998.

Uino, Pirjo. (1991) Inkerinmaan esihistoria. In P. Nevalainen and H. Sihvo (eds.), Inkeri: Historia, Kansa, Kulttuuri (pp. 11-34). Helsinki: SKS toimituksia 547.

Wiik, Kalevi. (2002) Eurooppalaisten juuret. Jyväskylä: Atena.

Zachrisson, Inger. (1997a) Skrivet och sagt. In Inger Zachrisson et al. (eds.), Möten $i$ gränsland. Samer och germaner $i$ Mellanskandinavien (pp. 158 - 175). Stockholm: Statens historiska museum/Stockholm monographs 4.

Zachrisson, Inger. (1997b) Varför samiskt? In Inger Zachrisson et al. (eds.), Möten $i$ gränsland. Samer och germaner i Mellanskandinavien (pp. 189 - 220). Stockholm: Statens historiska museum/Stockholm monographs 4. 